\title{
АСПЕКТИ НАВЧАННЯ СТУДЕНТІВ МЕТОДІВ ФУНКЦІОНАЛЬНОЇ ДІАГНОСТИКИ В ГАСТРОЕНТЕРОЛОГІї
}

\author{
T. A. Zaiets
}

\section{Horbachevsky Ternopil State Medical University \\ ASPECTS OF TEACHING STUDENTS THE METHODS OF FUNCTIONAL DIAGNOSTICS IN GASTROENTEROLOGY}

\begin{abstract}
Мета роботи - провести аналіз основних аспектів навчання студентів методів функціональної діагностики в гастроентерології, створення чіткої організації навчального процесу щодо вивчення матеріалу та постійного вдосконалення і поповнення теоретичних знань.

Основна частина. Проведено аналіз літературних даних та власного досвіду викладання дисципліни “Функціональна діагностика” з метою вибору оптимальних методів навчання та форм контролю набутих знань студентів з даної дисципліни, які навчаються за спеціальністю “Лікувальна справа”. Скорочення обсягу аудиторних годин, які відводяться для вивчення дисципліни, вимагає від викладача певну частину програмного матеріалу курсу виносити на самостійне опрацювання студентами. У свою чергу, це потребує від викладача правильного вибору засобів контролю знань студентів. У статті проаналізовано роль багатоваріантних та комплексних задач в організації контрольних заходів з метою перевірки якості засвоєння студентами програмного матеріалу курсу “Функціональна діагностика”.

Стаття розкриває роль поєднаної теоретичної підготовки з можливістю попрактикуватися на реальних пацієнтах, що дає можливість закріпити знання з дисципліни “Функціональна діагностика”.

Висновок. Чітка організація навчального процесу під час викладання розділу дисципліни “Методи функціональної діагностики в гастроентерології” для студентів VI курсу медичного факультету дозволить здобути відмінні практичні навички та вміння, а також створити міцне теоретичне підгрунтя.
\end{abstract}

Ключові слова: навчальний процес; функціональна діагностика; методи функціональної діагностики в гастроентерології.

The aim of the work - to analyze the main aspects of teaching students the methods of functional diagnosis in Gastroenterology to create a clear organization of the learning process and improvement and replenishment of theoretical knowledge.

The main body. The analysis of literary data and own experience of teaching the Functional Diagnostics discipline is conducted with the aim of choosing the best methods of teaching and the forms of discipline knowledge control in students, who study at the medical faculty. Decrease of the number of auditorium hours devoted to the discipline necessitates the lecturer to propose to the students some part of the program material for the self-study. This requires the correct choice of the means of students' knowledge control. In the article we analyzed the role of complex tasks in the organization of control measures aimed at checking the quality of learning by the students in "functional diagnostics". The article reveals the role of combined theoretical training with the ability to practice on real patients, which makes it possible to consolidate the knowledge of discipline "functional diagnostics."

Conclusion. A clear organization of the educational process during the teaching of the discipline section Methods of Functional Diagnosis in Gastroenterology for students of the VI course, the medical faculty will allow to obtain excellent practical skills and to create a solid theoretical foundation.

Key words: educational process; functional diagnostics; methods of functional diagnostics in gastroenterology.

Вступ. Чергова реформа охорони здоров'я в Україні висуває на перший план проблему підготовки висококваліфікованих спеціалістів, які були б конкурентоспроможні у всьому світі. Важлива роль у підвищенні професійного рівня студентів медичного університету належить продуманому, чітко організованому та всебічному навчанню. Функціональна діагностика - це один із розділів медичної науки, що поєднує в собі ряд діагностич(C) Т. А. Заєць них процедур, які дозволяють об'єктивно оцінити функціональні можливості всіх органів і систем людського організму [1].

Вивчення методів функціональної діагностики студентами-медиками дає можливість у практичній роботі виявити відхилення, об'єктивно їх оцінити і визначити рівень порушення функцій різних органів та фізіологічних систем організму на основі отриманих результатів, а також розширює і поглиблює професійні знання майбутніх фахівців. 
Методи функціональної діагностики допомагають лікарю не лише зробити медичний висновок, а й проводити динамічне спостереження за станом здоров'я пацієнта протягом усього періоду лікування і точно визначити ефективність подальшого терапевтичного впливу. Саме комплексне обстеження під контролем фахівців різного профілю дозволяє виявити багато небезпечних захворювань на найбільш ранніх етапах їхнього розвитку [2].

Мета роботи - провести аналіз основних аспектів навчання студентів методів функціональної діагностики в гастроентерології, створення чіткої організації навчального процесу щодо вивчення матеріалу та постійного вдосконалення і поповнення теоретичних знань.

Основна частина. Впровадження в навчальний процес дисципліни “Функціональна діагностика” для студентів 6 курсу на кафедрі функціональної і лабораторної діагностики є важливим та практично обгрунтованим. У цей період навчання вони вже освоїли всі базові та більшість клінічних дисциплін, сформували уявлення про причини та механізми розвитку хвороб, їх клініко-лабораторні прояви, принципи лікування. Викладання функціональної діагностики в рамках внутрішньої медицини $€$ важливим моментом для узагальнення раніше вивченого, а також розвитку у майбутніх лікарів клінічного мислення щодо правильного формування клінічного діагнозу з використанням додаткових методів дослідження [3]. Кожен клінічний випадок повинен розглядатися на основі детального аналізу всіх отриманих даних. 3 їх урахуванням обгрунтовується призначення відповідних діагностичних методик та терапевтичних схем. Саме за допомогою додаткових функціональних методів обстеження можливо виключити чи підтвердити патологію при захворюванні органів та систем організму.

Викладання дисципліни ведеться за принципами наочності і послідовності викладання навчального матеріалу, індивідуального підходу до навчання та поточного контролю знань. Змістом навчання функціональної діагностики в гастроентерології є викладання систематичних знань про основні методи дослідження функцій шлунково-кишкового тракту. На даний час лікарями загальної практики - сімейної медицини, гастроентерологами дані анамнезу часто недооцінюються, вони непереконливі, мають певні протиріччя, потребують деталізації, до того ж іноді пацієнт не може чітко та однозначно відповісти на запитання. Значення глибокого розуміння закономірностей перебігу різних видів патологій органів шлунково-кишкового тракту в організмі людини постійно зростає у зв'язку з тією обставиною, що підходи та методи посідають чільне місце в діагностичному процесі, контролі за перебігом хвороби та ефективністю лікування [4]. Особливо в разі порушення кислотоутворюючої та моторної функцій верхніх відділів ШКТ, частка яких значно переважає різні види органічної патології [5]. Тому вагоме місце для підтвердження чи спростування діагнозу, вирішення тактики подальшого ведення хворого займають методи функціональної діагностики, які студенти вивчають протягом заняття [6]. Перед студентами формулюються такі завдання: згрупувати виявлені симптоми в синдроми; виділити провідний синдром, за яким провести диференційну діагностику захворювання; сформулювати попередній діагноз; скласти план методів обстеження, які доречні для підтвердження даного діагнозу конкретного хворого, виходячи з аналізу причин, механізмів розвитку хвороби, її симптомів.

Для функціональної діагностики ключовими питаннями $є$ оволодіння на практичній частині заняття такими методиками дослідження функцій

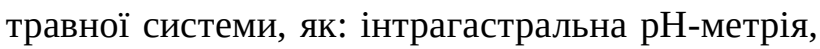
добова рНметрія, електрогастроентерографія, езофагогастродуоденоскопія, УЗД-діагностика, дуоденальне зондування. Під час дискусійного обговорення студенти проводять розбір клінічних ситуацій, аналіз історій хвороб, складають економічно рентабельну програму обстеження пацієнта. Основний акцент викладач робить на показаннях і протипоказаннях до проведення обстежень, інтерпретації виявлених змін, а також диференційованому призначенні різних методів діагностики. Ступінь засвоєння навчального матеріалу оцінюється з використанням відповідних контролюючих програм та шляхом аналізу тестових завдань з бази "Крок-2".

Застосування практично-орієнтованого навчання на кафедрі функціональної і лабораторної діагностики сприяє підвищенню мотивації студентів до майбутнього професійного розвитку. Різноплановість у підходах до навчального процесу студентів визначає професійну компетентність майбутніх фахівців. А це означає: базовий рівень освіти, прагнення до подальшої самоосвіти, творче й аналітичне мислення, цілеспрямований пошук, збір та узагальнення необхідної інформації, уміння прогнозувати ситуації, прагнення до досконалості, відстоювання власних позицій, компетентний підхід до клінічних ситуацій [7]. 
Висновки. 1. Викладання методів функціональної діагностики в гастроентерології студентаммедикам повинно бути практично-орієнтованим, що передбачає вивчення теоретичних положень і їх клінічне осмислення, обгрунтування функціональних методів у діагностичному процесі.

\section{Список літератури}

1. МайданникВ.Г. Римські критерії III(2006)діагностики функціональних гастроінтестинальних розладів у дітей / В. Г. Майданник // Педіатрія, акушерство та гінекологія. 2007. - № 3. - С. 5-13.

2. Функциональная диагностика в гастроэнтерологии : учебно-методическое пособие / О. А. Саблин, В. Б. Гриневич, Ю. П. Успенский, В. А. Ратников. - СПб., 2002. С. 80-83.

3. Симоненко В. Б. Функциональная диагностика / В. Б. Симоненко, А. В. Цоколов, А. Я. Фисун. - М. : Медицина, 2005. - 304 с.

4. Фундаментальные и клинические аспекты гастроэнтерологии / М. А. Медведев, М. Б. Баскаков,
2. Вдосконалення, розширення бази клінічних ситуаційних завдань, що вимагають логічного мислення, впровадження їх у навчальний процес є запорукою кращого засвоєння студентами матеріалу та впровадження отриманих знань у клініці. Практичні завдання повинні відображати найважливіші методи обстеження шлунково-кишкового тракту.

В. Н. Васильев, Э. И. Белобородова // Бюл. Сиб. отделения РАМН. - 2006. - № 2. - С. 69-74.

5. Hasler W. L. Gastroparesis - current concepts and considerations / W. L. Hasler // Medscape J. Med. - 2008. Vol. 10, No. 1. - P. 16.

6. Кудрявая Н. В. Педагогика в медицине : учебное пособие / Н. В. Кудрявая, Е. М. Уколова, Е. А. Смирнова // Бюллетень сибирской медицины. - 2014. - Т. 13, № 3. С. $126-131$.

7. Мягков И. Ф. Медицинская психология. Учебник для вузов / И. Ф. Мягков, С. Н. Боков. - М. : Издательская корпорация “Логос”, 2010. - 232 с.

\section{References}

1. Maidannyk, V.H. (2007). Rymski kryterii III (2006) diahnostyky funktsionalnykh hastrointestinalnykh rozladiv [Roman principles III (2006) diagnosis of functional gastrointestinal disorders]. Kyiv: “Avanpost-Prym” [in Ukrainian].

2. Sablin, O.A. (2002). Funktsionalnaya diagnostika $v$ gastroenterologii [Functional diagnostics in gastroenterology]. Kyiv: Znannia [in Russian].

3. Simonenko, V.B., \& Tsokolov, A.V. (2005). Funktsionalnaya diagnostika [Functional diagnostics in gastroenterology]. Kyiv: Meditsina [in Russian].

4. Medvedev, M.A., Baskakov, M.B., Vasilev, V.N., \& Beloborodova, E.I. (2006). Fundamentalnye i klinicheskie

aspekty gastroenterologii [Fundamental and clinical aspects of Gastroenterology]. Byul. Sib. Otdeleniya RAMN - Journal of Siberian Medicine RAMN, 2, 69-74 [in Russian].

5. Hasler, W.L. (2008). Gastroparesis - current concepts and considerations. Medscape J. Med., 10, 16 [in Ukrainian].

6. Kudryavaya, N.V., Ukolova, E.M., \& Smirnova, E.A. (2014). Pedagogika v meditsine: uchebnoe posobie [Pedagogy in medicine: textbook]. Byulleten sibirskoy meditsinyJournal of Siberian Medicine, 13 (3), 126-131[in Russian].

7. Myagkov, I.F., \& Bokov, S.N. (2010). Meditsinskaya psikhologiya. Uchebnik dlya vuzov [Medical psychology. Textbook for high schools]. Moscow: Izdatelskaya korporatsiya "Logos" [in Russian]. 